\title{
The Assimilate Partitioning Importance for Heartwood Extractives Formation in Robinia Pseudoacacia 1. of Different Ages
}

\author{
Oliver Dünisch ${ }^{1}$, João Vicente de Figueiredo Latorraca² \\ ${ }^{1}$ Meisterschule Ebern für das Schreinerhandwerk, Ebern, Alemanha \\ ${ }^{2}$ Departamento de Produtos Florestais, Universidade Federal Rural do Rio de Janeiro - UFRRJ, Seropédica/RJ, Brasil
}

\begin{abstract}
This study aimed to investigate the influence of tree age on the assimilates partitioning and its significance for the formation of heartwood extractives in Robinia pseudoacacia L. (black locust). Assimilate translocation in 6- and 15-year-old plants was measured in May and August 2006 using the ${ }^{14} \mathrm{CO}_{2}$ feeding method. The heartwood extractives content in the sapwood-heartwood transition zone and in individual tree rings of the pure heartwood were analysed by HPLC-chromatography. All plants, buds and young leaves showed the strongest $14 \mathrm{C}$ specific activity compared to other plant parts in May and August $\left({ }^{14} \mathrm{C}\right.$ specific activity in buds/leaves of 6 -years old plants: 35.2-37.0\%, 15-years old plants: 31.4-32.2\%). However, in plants labelled in August 2006 at the sapwood-heartwood transition zone also showed a strong assimilates sink, while only small amounts of assimilates were translocated to the sapwood-heartwood transition zone in the plants labelled in May 2006. The amount of assimilates transported to the sapwood-heartwood transition zone was significantly higher in the 15-year-old plants compared to the 6-year-old plants. This was monitored by a higher content of extractives in the heartwood formed by the older plants compared to heartwood formed by the younger plants. The results indicate that uneven assimilate partitioning in younger and older black locust plants affects the heartwood extractives formation, which might lead to a lower natural durability of the heartwood formed by younger trees compared to heartwood formed by older trees.
\end{abstract}

Keywords: juvenile wood, mature wood, heartwood durability, assimilate labelling.

\section{Importância da Distribuição de Assimilados para a Formação dos Extrativos do Cerne em Robinia Pseudoacacia L. de Diferentes Idades}

\begin{abstract}
RESUMO
O objetivo deste trabalho foi estudar a influência da idade da árvore na distribuição de assimilados e na formação de extrativos do cerne de Robinia pseudoacacia. A translocação de assimilados em plantas de 6 e 15 anos de idade foi mensurada em maio e em agosto de 2006, por meio do método do carbono 14. Os teores de extrativos na madeira da zona de transição entre o cerne e o alburno e em anéis de crescimento do cerne foram analisados por HPLC. Em maio e em agosto, em todas as plantas, os brotos e as folhas jovens tiveram a atividade específica do 14C mais forte, quando comparados com outras partes da planta (atividade específica de $14 \mathrm{C}$ em brotos/folhas de plantas de 6 anos de idade: 35,2-37,0\%; plantas de 15 anos de idade: 31,4-32,2\%). No entanto, em plantas analisadas em agosto de 2006, na zona de transição entre o cerne e o alburno, houve também um forte sequestro de assimilados, enquanto que, nas plantas analisadas em maio de 2006, apenas pequenas quantidades de assimilados foram translocadas. A quantidade de assimilados
\end{abstract}


transportados para a zona de transição entre o cerne e o alburno, foi significativamente maior em plantas de 15 anos de idade, em comparação com as de 6 anos de idade. Isso foi acompanhado por um teor mais elevado de extrativos no cerne formado pelas plantas mais velhas em relação ao cerne da madeira formada pelas plantas jovens. Os resultados indicam que a distribuição desigual de assimilados em plantas de Robinia mais jovens e mais velhas afeta a formação de extrativos de cerne, o que pode levar a uma menor durabilidade natural do cerne formado por árvores mais jovens em relação ao cerne formado por árvores mais velhas.

Palavras-chave: lenho juvenil, lenho adulto, durabilidade do cerne, assimilados.

\section{INTRODUCTION}

During the last years, the demand for highly durable timber strongly increased. Therefore, tree species, which produce timber of a high natural durability have been heavily exploited in natural forests, leading to low remaining stocks of old-grown trees. As a consequence, on the timber market the portion of timber from younger trees grown in natural forests or grown in fast rotation plantations increased significantly.

At the same time, reports from practice indicated a decrease of natural durability of the heartwood of timber from some species, which are considered to produce the best quality of timber for outdoor constructions. In particular, a lower concentration of wood extractives was found in the juvenile heartwood of Tectona grandis (Teak) compared to the mature heartwood corresponding to a lower natural durability of heartwood formed by younger trees compared to heartwood formed by older trees (Bhat \& Florence, 2003; Haupt et al., 2003). Similar results are reported for Robinia pseudoacacia L. (black locust; Dünisch et al., 2007), one of the most promising species for the production of highly durable heartwood in North America and in Europe (Stringer \& Olson, 1987; Adamopoulus et al., 2005). However, there is a high number of further high quality timber species without significant differences in the natural durability of the heartwood formed during the juvenile phase of growth and the adult phase of growth (Zobel \& Sprague, 1998).

Several studies proved significant differences in biomass partitioning between younger and older trees (Kozlowski et al., 1991). In particular, the portion of young leaves and roots is significantly higher in younger trees compared to older trees, while the proportion of biomass located in the stem increases with tree age. As a consequence, the strong preference of primary growth in younger plants might lead to a reduced availability of assimilates for secondary changes (e.g. formation of heartwood extractives) in younger trees.

With this in mind, the aim of the present study was to investigate the relationship between the partitioning of assimilates and the formation of heartwood extractives in younger and older Robinia pseudoacacia L. trees. The investigations were carried out with special regard to the minimum rotation time for the formation of high quality heartwood in this species.

\section{MATERIAL AND METHODS}

\subsection{Experimental plants}

For the preparation of genetically identical plant material, 21 cuttings from coppice shoots of one mother tree grown at the experimental area of the Forest Research Centre for Forestry and Forest Products, Großhansdorf, Germany were collected (Figure 1a-c). The age of the cuttings was quantified by counting the number of tree rings at the cross section area. The age of the cuttings varied between 3 and 17 years. For root formation the cuttings were cultivated in a "Knop" nutrient solution for one month. After that the cuttings were planted in a stool bed. After a four months growing period in the field, the plants were transferred into pots with a standard soil substrate (Dünisch et al., 2006) and cultivated in the greenhouse of the Federal Research Centre for Forestry and Forest Products under local climate conditions.

Two 6- and 15-year-old plants were selected for the experiments on the spatial distribution of photosynthetic assimilates carried out in May 2006 and August 2006. Assimilate translocation was measured using the ${ }^{14} \mathrm{CO}_{2}$ steady-state feeding method (Shishido et al., 1999; Zgallai et al., 2006). The radioactive pulse was given to the $4^{\text {th }}$ to $6^{\text {th }}$ leaf counted from the top of the plant (leaves below the dotted line in Figure 2) representing 
8.3 to $12.7 \%$ of the total leaf area of the plants. The leaves were hermetically confined in a cuvette (CRS 087, PP systems, UK). $15 \mu \mathrm{Na}_{2}{ }^{14} \mathrm{CO}_{3}$ (specific activity $53 \mathrm{mCi} \mathrm{mmol}^{-1}$; Amersham, UK) was put in a reservoir inside the cuvette and $100 \mu \mathrm{l} \mathrm{HCl}\left(10^{-5} \mathrm{M}\right)$ was added to the carbonate to form ${ }^{14} \mathrm{CO}_{2}$. After a translocation period of 10 days, the plants were separated into different plant fractions (Figure 2). The dry mass and the water content of the plant fractions were quantified according to the European standard EN 13183.
The radioactivity in the plant fractions was quantified by means of a scintillation counter (NAIS $3 \times 5 \times 16$ LED detector, Canberra Industries). The samples were combusted in oxygen (Mod. 306 sample oxidizer, Packard Instruments) evolving the carbon as ${ }^{14} \mathrm{CO}_{2}$. The radioactivity in each sample was expressed in terms of relative specific activity, which is the ratio of the specific activity in the sample (radioactivity per $g$ dry weight) to the specific activity of the whole plant (Mor \& Halevy, 1979; Zgallaï et al., 2006).
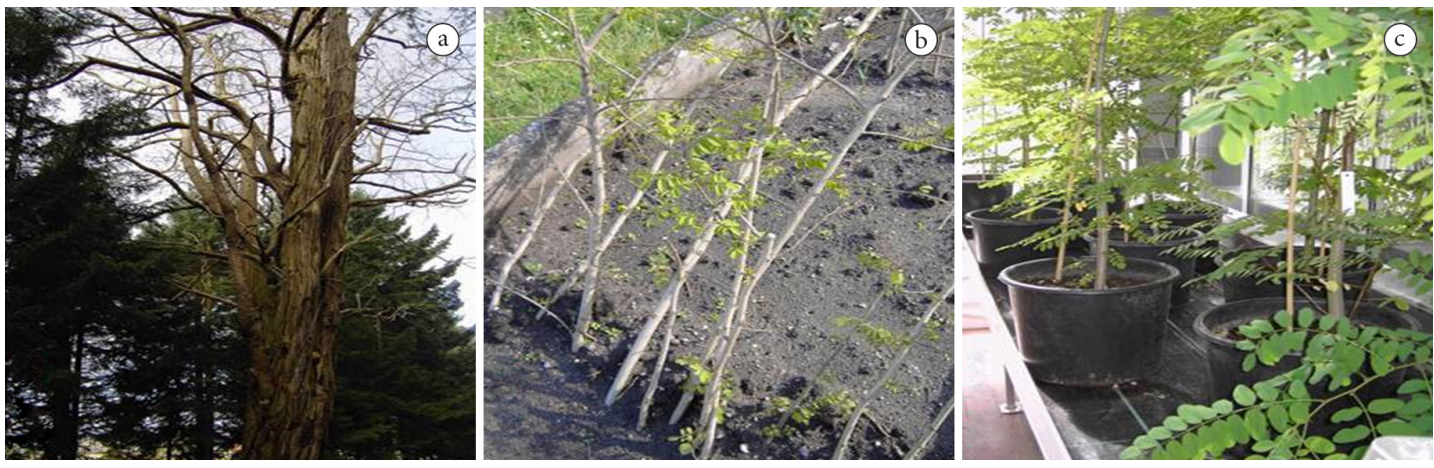

Figure 1. Preparation of experimental plants for the labelling experiments (a) Mother tree of the 4- to 17-year-old cuttings; (b) Root formation of the cuttings under field conditions; (c) Cultivation of the plants under controlled climate conditions in the greenhouse.

Figura 1. Preparação das plantas para o experimento (a) árvore-mãe de 4 a 17 anos de idade; (b) Formação das raízes em condições de campo; (c) Cultivo de plantas sob condições climáticas controladas em casa de vegetação.

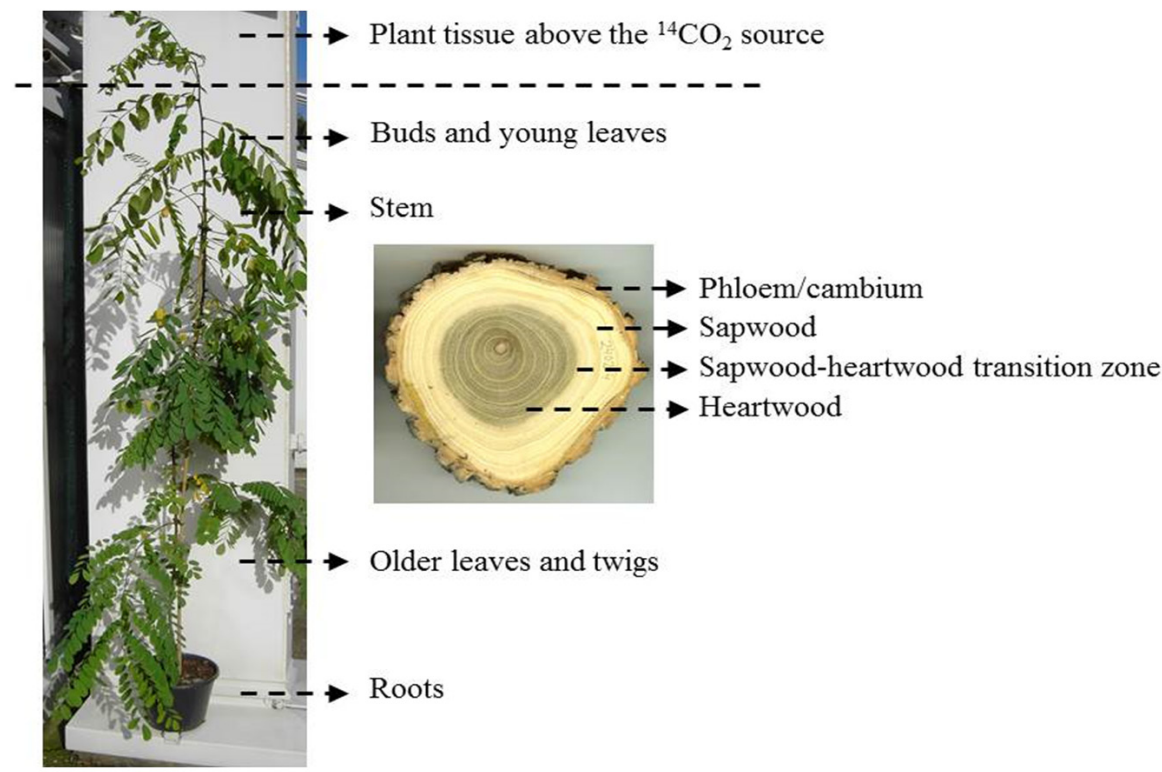

Figure 2. Fractioning of the labelled plants for the determination of the biomass and the specific activity $(\%)$ of ${ }^{14} \mathrm{C}$ in different plant tissues.

Figura 2. Fracionamento das plantas estudadas para a determinação da biomassa e atividade específica (\%) de ${ }^{14} \mathrm{C}$ em diferentes tecidos da planta. 


\subsection{Chemical analysis of heartwood extractives}

For qualitative and quantitative analyses of heartwood extractives in the cuttings, shavings of individual tree rings were prepared from pith to bark. The shavings were immediately freeze dried and ground in a Retsch mill with a rotating knife using a $3 \mathrm{~mm}$ screen, followed by accelerated solvent extraction (ASE 200, Dionex). Extractions were carried out with acetone/water (9:1) and methanol/-water $(3: 1)$ at $60{ }^{\circ} \mathrm{C}$ under constant pressure at $100 \mathrm{~atm}$ and a static equilibration treatment of $5 \mathrm{~min}$. according to Koch et al. (2006).

A total of $5 \mathrm{ml}$ of acetone/water extract of the samples without derivatization were directly injected into a Jasco system using an Aquasil $5 \mu \mathrm{C} 18$ column $(250 \times 4.6 \mathrm{~mm})$. The temperature of the column was set at $30{ }^{\circ} \mathrm{C}$. Solvent $\mathrm{A}\left(0.001 \mathrm{~m} \mathrm{H}_{3} \mathrm{PO}_{4}\right)$ and solvent $\mathrm{B}$ (acetonitrile 100\%) served as mobile phase in a gradient mode (7.5-15\% B at 0-30 min., $15-20 \%$ $\mathrm{B}$ at $30-40$ at $40-60 \mathrm{~min} ., 40-100 \% \mathrm{~B}$ at $60-65 \mathrm{~min}$.) with a flow rate of $1 \mathrm{ml} / \mathrm{min}$. The separated compounds were detected with a Jasco photo diode array detector. The detection wavelength was set at $280 \mathrm{~nm}$ and UV spectra from 200 to $650 \mathrm{~nm}$ were also recorded for peak identification. Peak identification was performed by comparison of retention times and UV spectra with purchased standards (Sigma Aldrich). For quantification, calibration curves with four calibration points for each substance were set. Quantification was performed in triplicate.

\section{RESULTS}

\subsection{Content of robinetin and dihydrorobinetin} in the heartwood of 6-and 15-year-old cuttings

The analyses of heartwood extractives in individual tree rings from the cambium to the pith showed that heartwood formation starts in the third growth increment (tree ring no. 4 in the 6-year-old plant and tree ring no. 13 in the 15-year-old plant, Figure 3 ) and is completed after 2 to 3 years as a maximum (sapwood-heartwood transition zone, Figure 3). The separation of the extractives by HPLC-chromatography showed that in the heartwood of black locust robinetin and dihydrorobinetin are the dominant components. In the sapwood-heartwood transition zone robinetin was formed during the early phase of heartwood formation, while dihydrorobinetin was formed during the later phase of heartwood formation.

In the heartwood of the 6- and the 15-year-old plants the content of robinetin and dihydrorobinetin increased from the pith to the heartwood boundary indicating a reduced content of heartwood extractives in heartwood formed during the juvenile phase of tree growth compared to heartwood formed during the adult phase of tree growth. This result was confirmed by the lower content of heartwood extractives in the tree rings of the 6-year-old plants compared to the tree rings formed at the same time in the 15 -year-old plants.
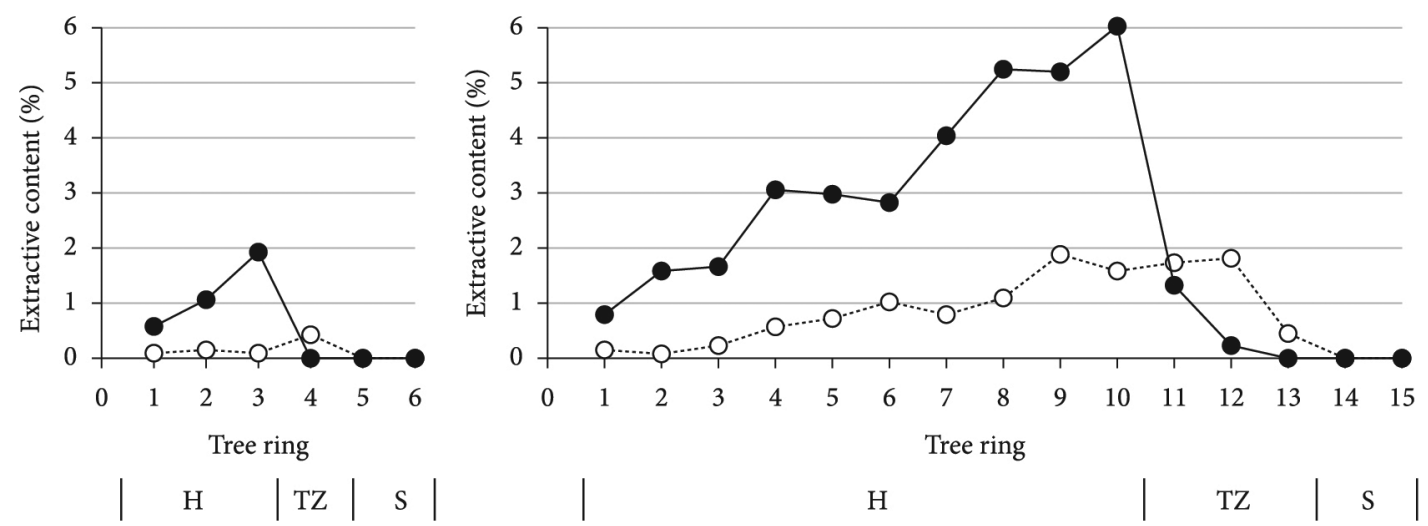

Figure 3. Extractive content (\%) in the xylem of the 6- and 15-year-old plants selected for the labelling experiments. $\mathrm{H}=$ Heartwood, $\mathrm{TZ}=$ Sapwood-heartwood transition zone, $\mathrm{S}=$ Sapwood.

Figura 3. Teor de extrativos do xilema de plantas de 6 e 15 anos de idade selecionadas para o experimento. $\circ$ Robinetin, $\bullet$ Dihydrorobinetin. $\mathrm{H}=$ Cerne, $\mathrm{TZ}=$ Zona de transição cerne-alburno, $\mathrm{S}=$ Alburno. 


\subsection{Biomass partitioning in the 6- and 15-year-old labelled plants}

The total plant biomass of the 15-year-old plants was 4 to 5 times higher than the biomass of the 6-year-old plants (Table 1). In all plants more than $76 \%$ of the total biomass were located in the stem and in the roots. In the stem of the plants, the sapwood was the major biomass fraction, while only 1.9 to $2.9 \%$ of the biomass were located in the sapwood-heartwood transition zone.

In the older plants the portion of biomass located in the buds, in the young leaves, and in the roots decreased compared to the younger plants, while the portion of biomass located in the stem increased. In the stem of the 15-year-old plants the portion of the biomass located in the sapwood was lower than in the 6-year-old plants, while the portion of heartwood increased.

\subsection{Specific activity of ${ }^{14} \mathrm{C}$ in the 6- and 15-year-old labelled plants}

After ten days of labelling, a very high specific activity of ${ }^{14} \mathrm{C}$ was found in the buds, in the leaves, in the secondary phloem, and in the roots of the plants labelled in May as well as in August 2006 (Table 2). In contrast, the specific activity of ${ }^{14} \mathrm{C}$ in the sapwood and in the heartwood was low $(<2 \%)$. In plants labelled in May the specific activity of ${ }^{14} \mathrm{C}$ in the sapwood-heartwood transition zone was $0.4 \%$ in the 6 -year-old plant and $0.5 \%$ in the 15 -year-old

Table 1. Biomass (g: portion of total plant biomass \%) of the 6-year-old and 15-year-old Robinia pseudoacacia plants selected for the labelling experiments in May and August 2006.

Tabela 1. Biomassa (g: parcela do total de biomassa vegetal \%) de plantas Robinia pseudoacacia de 6 e 15 anos de idade selecionadas para os experimentos de maio e agosto de 2006.

\begin{tabular}{ccccc}
\hline & \multicolumn{2}{c}{ May 2006 } & \multicolumn{2}{c|}{ August 2006 } \\
\cline { 2 - 5 } Plant tissue & $\mathbf{6}$ years & $\mathbf{1 5}$ years & $\mathbf{6}$ years & $\mathbf{1 5}$ years \\
\hline $\begin{array}{c}\text { Plant tissue above } \\
{ }^{14} \mathrm{CO}_{2} \text { source }\end{array}$ & $27(4.3 \%)$ & $138(4.6 \%)$ & $23(3.9 \%)$ & $74(2.8 \%)$ \\
\hline $\begin{array}{c}\text { Buds and young leaves } \\
\text { Older leaves and twigs }\end{array}$ & $19(3.0 \%)$ & $60(2.0 \%)$ & $6(1.0 \%)$ & $15(0.1 \%)$ \\
\hline $\begin{array}{c}\text { Stem: Phloem/ } \\
\text { cambium }\end{array}$ & $17(7.4 \%)$ & $473(15.8 \%)$ & $54(9.2 \%)$ & $502(18.2 \%)$ \\
\hline $\begin{array}{c}\text { Stem: Sapwood } \\
\text { Stem: Transition zone }\end{array}$ & $169(16.2)$ & $586(19.6 \%)$ & $69(11.7 \%)$ & $597(21.7 \%)$ \\
sapwood-heartwood & $13(2.1 \%)$ & $709(23.7 \%)$ & $201(34.1 \%)$ & $613(22.3 \%)$ \\
\hline Stem: Heartwood & $47(7.4 \%)$ & $60(2.0 \%)$ & $17(2.9 \%)$ & $53(1.9 \%)$ \\
\hline Roots & $207(32.8 \%)$ & $344(11.5 \%)$ & $36(6.1 \%)$ & $403(14.7 \%)$ \\
\hline Total & $631(100 \%)$ & $617(20.8 \%)$ & $184(31.2 \%)$ & $501(18.3 \%)$ \\
\hline
\end{tabular}

Table 2. Specific activity (\%) of ${ }^{14} \mathrm{C}$ in different plant tissues of 6-year-old and 15-year-old Robinia pseudoacacia after ten days of labelling in May and August 2006.

Tabela 2. Atividade específica (\%) de ${ }^{14} \mathrm{C}$ em diferentes tecidos de plantas de 5 e 15 anos de idade de Robinia pseudoacacia selecionadas para os experimentos de maio e agosto de 2006.

\begin{tabular}{|c|c|c|c|c|}
\hline \multirow{2}{*}{ Plant tissue } & \multicolumn{2}{|c|}{ May 2006} & \multicolumn{2}{|c|}{ August 2006} \\
\hline & 6 years & 15 years & 6 years & 15 years \\
\hline Plant tissue above ${ }^{14} \mathrm{CO}_{2}$ source & 20.6 & 16.6 & 17.4 & 10.2 \\
\hline Buds and young leaves & 37.0 & 32.2 & 35.2 & 31.4 \\
\hline Older leaves and twigs & 2.7 & 5.4 & 14.0 & 19.1 \\
\hline Stem: Phloem/cambium & 25.3 & 31.8 & 21.0 & 18.6 \\
\hline Stem: Sapwood & 1.9 & 1.7 & 1.4 & 1.9 \\
\hline Stem: Transition zone sapwood-heartwood & 0.4 & 0.5 & 2.7 & 7.1 \\
\hline Stem: Heartwood & $<0.1$ & $<0.1$ & $<0.1$ & $<0.1$ \\
\hline Roots & 12.0 & 11.7 & 8.3 & 11.7 \\
\hline
\end{tabular}


plant, while in the plants labelled in August the specific activity in the sapwood-heartwood transition zone was 2.7 and $7.1 \%$, respectively.

Sink regions for ${ }^{14} \mathrm{C}$ within the plants were identified by dividing the specific activity of ${ }^{14} \mathrm{C}$ in the different plant fractions through the corresponding portion of biomass (Table 1 and 2). In all plants the buds, the young leaves, the secondary phloem, and the cambium of the stem were strong sinks for labelled carbon. In comparison to the portion of biomass, relatively small amounts of labelled assimilates were found in the roots, in the sapwood as well as in the heartwood of the stem. In the sapwood-heartwood transition zone of plants labelled in May 2006 the relation between the specific activity of ${ }^{14} \mathrm{C}$ and the portion of biomass was 0.2 in the 6-year-old plant and 0.3 in the 15 -year-old plant indicating that in May the sapwood-heartwood transition zone is not a strong sink for assimilates. In the plants labelled in August the relationship was 1.1 in the 6-year-old plants and 3.7 in the 15-year-old plant indicating that at the end of the vegetation period in particular in older plants the sapwood-heartwood transition zone is a very strong sink for assimilates.

\section{DISCUSSION AND CONCLUSION}

For the study on the relationship of assimilate partitioning and heartwood formation genetically identical cuttings of Robinia pseudoacacia were chosen, because heartwood formation in trees is considered to be under strong genetic control (Hillis, 1987; Yang et al., 2004). However, during the first years plants from cuttings have a lower root biomass compared to plants originated from seeds (Kozlowski et al., 1991). This might had a significant impact on the water and nutrient transport as well as on the partitioning of assimilates within the experimental plants in absolute numbers, while no significant impact of the treatment on the relative distribution of assimilates within the experimental plants can be expected (all cuttings were produced at the same time). In addition, the biomass of the plants selected for the labelling experiments carried out in August was slightly reduced compared to the plants selected for the labelling experiments in May, although from the statistical point of view the older plants should have a higher biomass than the younger plants. In order to consider the influence of different biomasses of the experimental plants on the uptake of ${ }^{14} \mathrm{CO}_{2}$, the assimilate partitioning within the plants was quantified in relative numbers (\%) and not in absolute numbers (g).

Changes in assimilate translocation within 6-and 15 -year-old plants were studied using the ${ }^{14} \mathrm{CO}_{2}$ steady-state feeding method. After 10 days of translocation a higher portion of the fixed ${ }^{14} \mathrm{C}$ was transferred to the lower parts of the plants than to the plant fractions above the source leaves. This is in agreement with results from other labelling experiments indicating a dominant assimilate flux in the secondary phloem stem downwards (Bota et al., 2004; Zgallaï et al., 2006). Due to the higher distance of the roots and the stem zone under investigation as well as due to the low velocity of assimilate transport in the phloem (Sauter, 2000), the roots, the cambium, and the sapwood-heartwood transition zone are slightly underestimated as a sink for assimilates. In contrast, in our experimental approach the sink function of plant parts close to the source leaves (buds, leaves, twigs) is slightly overestimated.

In plants labelled in May 2006 the amount of labelled assimilates transferred to the sapwood-heartwood transition zone was low, while in plants labelled in August 2006 the portion of assimilates transferred to the sapwood-heartwood transition zone was high. This is in agreement with former studies of Hillinger et al. (1996) and Magel et al. $(1991,1994)$ indicating that the main steps of heartwood formation occur at the end of the vegetation period. In particular, the formation of heartwood extractives in the sapwood-heartwood transition zone needs a strong supply of this region with assimilates. The strong flux of ${ }^{14} \mathrm{C}$ from the source leaves to the sapwood-heartwood transition zone in August indicates that most of the assimilates came from the recent photosynthetic activity, while the use of reserve materials for the formation of heartwood extractives seems to be of less importance.

The portion of ${ }^{14} \mathrm{C}$ translocated to the sapwoodheartwood transition zone in August was higher in the 15-year-old plants than in the 6-years-old plant, while the portion of assimilates translocated to the buds and to the young leaves was lower. Many studies showed that during the juvenile phase of growth trees favour primary growth (buds, root tips), while secondary growth (cambium), and secondary changes (heartwood formation) are favoured during the adult phase of tree growth (Zobel \& Sprague, 1998). In tree species 
in which the formation of heartwood already starts during the juvenile phase of growth (like Robinia) heartwood formation competes with primary growth for leaf assimilates. As a consequence, during the juvenile phase of growth less assimilates are available for the formation of heartwood extractives.

This is confirmed by the reduced content of robinetin and dihydrorobinetin in the juvenile heartwood of the experimental plants. As a consequence, a reduced natural durability of the heartwood of Robinia pseudoacacia formed by younger trees compared to heartwood formed by older trees is expected. Former studies by Dünisch et al. (2010) proved this hypothesis. Our analyses of heartwood extractives in the individual tree rings of the experimental plants indicate that in black locust the natural durability of the innermost 5-9 heartwood tree rings is lower than of the mature heartwood. Therefore, for the silviculture of black locust we recommend long rotation times in order to produce a high portion of high quality heartwood in the stem.

\section{ACKNOWLEDGEMENTS}

We thank the Deutsche Gesellschaft für Holzforschung, Munich (DGfH/AiF 14276 BG/1 N), the German Academic Exchange Service (DAAD), and the CNPq, Brasilia for financial support. We are indebted to Prof. Dr. Wolfgang Heyser and his group, University of Bremen, for helpful advice and discussion on ${ }^{14} \mathrm{CO}_{2}$ labelling. The technical assistance of Otto Rühmann, von Thünen Institute Hamburg and the improvement of the manuscript by two unknown reviewers are especially appreciated.

\section{SUBMISSION STATUS}

Received: 19 mar., 2014

Accepted: 8 june, 2015

\section{CORRESPONDENCE TO}

\section{João Vicente de Figueiredo Latorraca}

Departamento de Produtos Florestais, Universidade Federal Rural do Rio de Janeiro UFRRJ, Rodovia BR 465, Km 07, Seropédica, RJ, Brasil

e-mail: latorraca@hotmail.com

\section{REFERENCES}

Adamopoulus S, Voulgaridis E, Passialis C. Variation of certain chemical properties within the stemwood of black locust (Robinia pseudoacacia L.). Holz als Roh- und Werkstoff 2005; 63(5): 327-333. http://dx.doi.org/10.1007/ s00107-005-0018-3.

Bhat KM, Florence EJ. Natural decay resistance of juvenile teak wood grown in high input plantations. Holzforschung 2003; 57(5): 453-455. http://dx.doi.org/10.1515/HF.2003.067.

Bota J, Stasyk O, Flexas J, Medrano H. Effect of water stress on partitioning of 14C-labelled photosynthates in Vitis vinifera. Functional Plant Biology 2004; 31(7): 697-708. http://dx.doi.org/10.1071/FP03262.

Dünisch O, Fladung M, Nakaba S, Watanabe Y, Funada R. Influence of overexpression of a gibberelin 20-oxidase gene on the kinetics of xylem cell development in hybrid poplar (Populus tremula L. x P. tremuloides Michx.). Holzforschung 2006; 60(6): 608-617. http://dx.doi. org/10.1515/HF.2006.103.

Dünisch O, Koch G, Dreiner K. Verunsicherung über die Eigenschaften von Robinienholz. Holzzentralblatt 2007; 39: 1061-1062.

Dünisch O, Richter HG, Koch G. Wood properties of juvenile and mature heartwood in Robinia pseudoacacia L. Wood Science and Technology 2010; 44(2): 301-313. http://dx.doi.org/10.1007/s00226-009-0275-0.

Haupt M, Leithoff H, Meier D, Puls J, Richter HG, Faix O. Heartwood extractives and natural durability of plantation-grown teakwood (Tectona grandis L.): a case study. Holz als Roh- und Werkstoff 2003; 61(6): 473-474. http://dx.doi.org/10.1007/s00107-003-0428-z.

Hillinger C, Höll W, Ziegler H. Lipids and lipolytic enzymes in the trunkwood of Robinia pseudoacacia L. during heartwood formation. Trees 1996; 10(6): 366-381. http://dx.doi.org/10.1007/s004680050045.

Hillis WE. Heartwood and tree exudates. Berlin: Springer Verlag; 1987.

Koch G, Richter HG, Schmitt U. Topochemical investigation on phenolic deposits in the vessels of afzelia (Afzelia spp.) and merbau (Intsia spp) heartwood. Holzforschung 2006; 60(6): 583-588. http://dx.doi.org/10.1515/HF.2006.099.

Kozlowski TT, Kramer PJ, Pallardy SG. The physiological ecology of woody plants. San Diego: Acedemic Press; 1991.

Magel E, Jay-Allemand C, Ziegler H. Formation of heartwood substances in the stemwood of Robinia pseudoacacia L. II. Distribution of nonstructural carbohydrates and wood extractives across the trunk. Trees 1994; 8(4): 165-171. http://dx.doi.org/10.1007/BF00196843.

Magel EA, Drouet A, Claudot AC, Ziegler H. Formation of heartwood substances in the stem of Robinia pseudoacacia 
L. Trees 1991; 5(4): 203-207. http://dx.doi.org/10.1007/ BF00227526.

Mor Y, Halevy AH. Translocation of 14C-assimilarte in roses. I: The effect of the age of the shoot and location of the source leaf. Plant Physiology 1979; 45: 117-182.

Sauter J. Photosynthate allocation of the vascular cambium: facts and problems. In: Savidge RA, Barnett JR, Napier $\mathrm{R}$, editors. Cell and molecular biology of wood formation. Oxford: BIOS Scientific Publishers; 2000.

Shishido Y, Kumakura H, Nishizawa T. Carbon balance of a whole tomato plant and the contribution of source leaves to sink growth using the $14 \mathrm{CO} 2$ steady-state feeding method. Plant Physiology 1999; 106(4): 402-408. http:// dx.doi.org/10.1034/j.1399-3054.1999.106407.x.
Stringer JW, Olson JR. Radial and vertical variations in stem properties of juvenile black locust (Robinia pseudoacacia L.). Wood and Fiber Science 1987; 19: 59-67.

Yang J, Kamdem DP, Keathley DE, Han KH. Seasonal changes in gene expression at the sapwood-heartwood transition zone of black locust (Robinia pseudoacacia) revealed by cDNA microarray analysis. Tree Physiology 2004; 24(4): 461-474. http://dx.doi.org/10.1093/treephys/24.4.461. PMid:14757585.

Zgallaï H, Steppe K, Lemeur R. Effects of severe water stress on partitioning of $14 \mathrm{C}$-assimilates in tomato plants. Journal of Applied Botany and Food Quality 2006; 80: 88-92.

Zobel BJ, Sprague JR. Juvenile wood in forest trees. Berlin: Springer Verlag; 1998. 